\title{
44. SUMMARY: LEG 84, MIDDLE AMERICA TRENCH TRANSECT OFF GUATEMALA AND COSTA RICA ${ }^{1}$
}

\author{
Jean Aubouin, Département de Géotectonique, Université Pierre et Marie Curie, Paris \\ and \\ Roland von Huene, U.S. Geological Survey, Menlo Park, California ${ }^{2}$
}

\section{INTRODUCTION AND PREVIOUS WORK}

At the beginning of the IPOD (International Program of Ocean Drilling) program in 1973, the Middle America Trench transect was assigned a high priority as a primary area for testing the accretionary convergent margin model based on an industry multichannel seismic record (Seely et al., 1974). The conditions favorable for testing accretion are present in the area; on the basis of earlier deep-sea drilling experience along convergent margins, these favorable conditions include good age resolution from a diverse community of microfossils, a moderate supply of terrigenous sediment, and a relatively rapid rate of convergence. The study of Seely et al. (1974) was based on one of the first published multichannel seismic records tied to a deep drill hole at the edge of the shelf (Seely, 1979). The case for accretion appeared convincing, and the Guatemalan segment of the Middle America Trench became a type example of convergent margin tectonism.

The first studies of the Guatemalan margin to follow those of Seely were the site surveys done in preparation for the drilling of Leg 67. A grid of multichannel seismic records made by the University of Texas (Ladd et al., 1978; Ibrahim et al., 1971) led to the selection of a transect about $70 \mathrm{~km}$ southeast of Seely's data that centered about San José Canyon where the cover of sediment above basement was thinnest. These were also the only records to show a landward-dipping reflection, which was the principal basis for the interpretation of imbrication and accretion. Ibrahim et al. (1979) and Ladd et al. (1982) emphasized the landward-dipping reflection and the rocks of high acoustic velocity that might be slices of igneous oceanic crust in the imbricated complex.

The Middle America Trench off Guatemala was first drilled in 1979 during Leg 67 (Fig. 1). The drilling proceeded smoothly on the Cocos Plate and in the Trench. For the first time the Trench itself was drilled down to the oceanic crust. Combined with the results of a postLeg Seabeam cruise by the Jean Charcot (Renard et al., 1980; Aubouin et al., 1981), the Leg 67 data made it clear that the Cocos Plate, with an inherited horst and

\footnotetext{
${ }^{1}$ von Huene, R., Aubouin, J., et al. Init. Repts. DSDP, 84: Washington (U.S. Govt. Printing Office).

Addresses: (Aubouin) Département de Géotectonique, Université Pierre et Marie Curie, 4 Place Jussieu, 75320 Paris Cedex 05, France; (von Huene) U.S. Geological Survey, Menlo Park, CA 94025.
}

graben structural trend oblique to the Trench axis, is subducted beneath the continental margin without any evidence of compressional structure. Extensional structure remains in the oceanic plate up to the very toe of the continental slope (Site 500), where the oceanic crust was drilled beneath a normal fault zone 75 to $135 \mathrm{~m}$ shallower than the middle of the Trench. This surprising result was explained by the Seabeam survey: Site 500 was located on the southwestern margin of a horst entering into the subduction zone (Fig. 2).

The presence of gas hydrates on the continental slope caused termination of Leg 67 drilling above the targeted objective for reasons of safety where the testing for imbrication required penetration of the slope deposits and sampling of the acoustic basement. There was one exception at the base of the slope where the drilling was successful in reaching basement, although this fact was not recognized at the time. A surprising sediment sequence from the Quaternary to Upper Cretaceous was recovered. Because of logistics, it was impossible to parallel the hole and sample well enough to show that the basement had been reached (an objective finally accomplished on Leg 84). Thus the scientific party of Leg 67 was repeatedly frustrated in reaching the tectonic targets planned for testing of an accretionary origin for the margin, and yet one hole displayed a section that precluded accretion at least in the Neogene. The tantalizing evidence for lack of accretion or even strong tectonism at the base of the landward slope of the Trench (undeformed trench fill continuing into the subduction zone, rocks as old as Late Cretaceous against the subduction Cocos Plate, and a cover of coherent slope sediment that extended into the early Neogene made this an obvious target for further drilling if the problems of safety could be overcome.

As a result of Leg 67 studies and some added geophysical work after the leg, geophysical data showed subduction of the Cocos Plate beneath Guatemala, but with only a few of the commonly observed features of accretion or compressional deformation. The present arctrench system left a good chronology of volcanic ash layers in the Neogene and this system had achieved maturity. According to the accretionary hypothesis there should be no remnants from the destruction of a previous margin. Nothing regarding the Trench morphology or the configuration of the forearc basin, the history of volcanism, seismicity seemed unusual, compared to other trenches of the Pacific. But clearly, the section of Upper Cretaceous to Quaternary rock at the front of the 


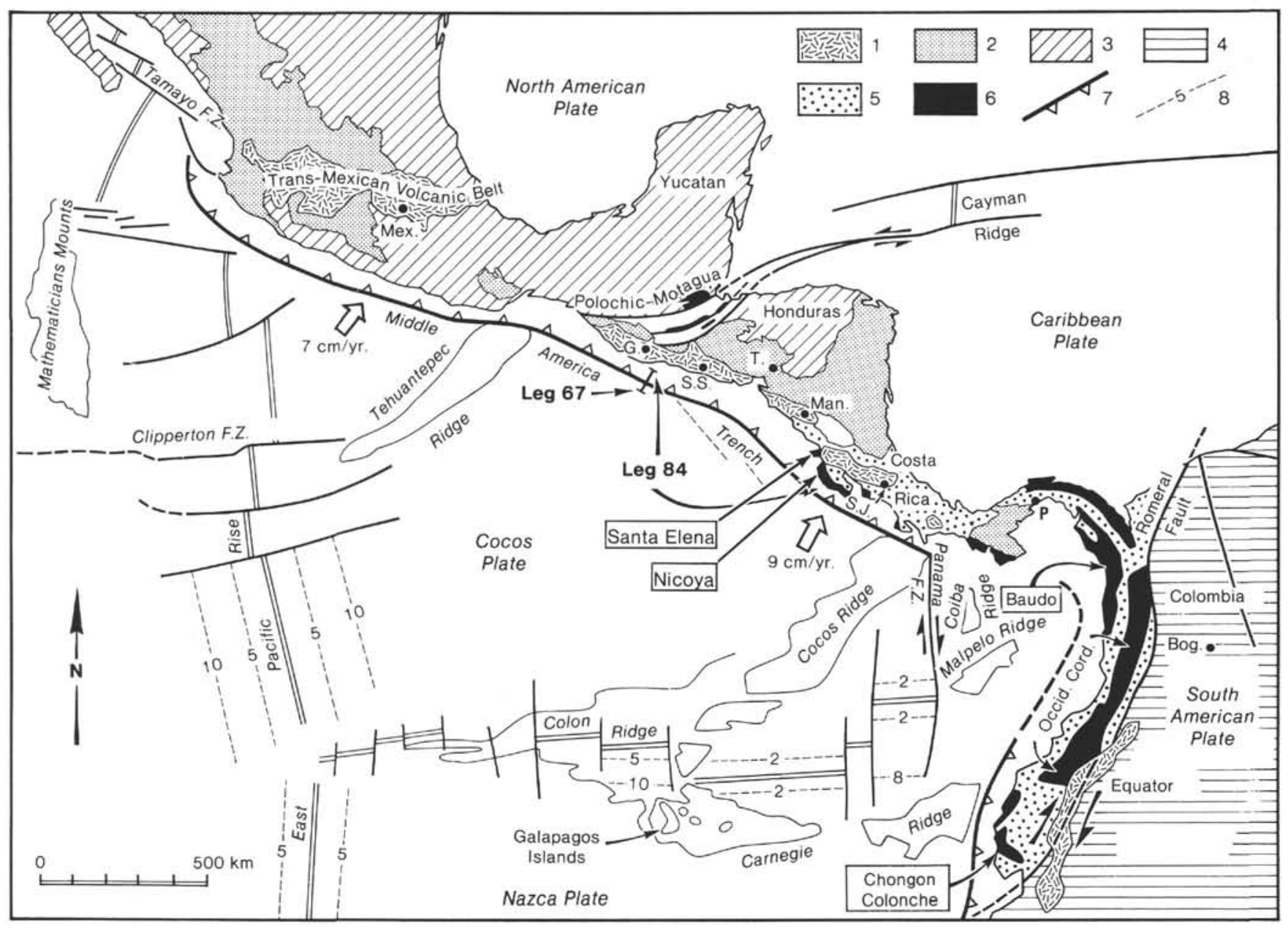

Figure 1. Tectonic setting of the Santa Elena and Nicoya peninsulas (Costa Rica) and of Legs 67 and 84 off Guatemala. Present-day plate motions from Minster and Jordan (1978). 1: Pliocene and Pleistocene volcanism; 2: Oligocene and Miocene; 3: North American Plate; 4: South American Plate; 5: Cenozoic formations of Andes and southern Central America; 6: Mesozoic and Cenozoic ophiolitic complexes; 7: subduction zones; 8: magnetic anomalies.

margin seemed to require some tectonic process other than accretion, and only one hole had penetrated the slope sediment. Despite recovery at only one hole, the old rock at the front of the Trench off Guatemala could not be dismissed out of hand as a local slump block or some other kind of accident.

Therefore, the objectives of Leg 84 were twofold. The first was to penetrate the slope deposits to examine the age and structure of the framework that forms the landward slope of the Trench off Guatemala. Because this objective had been frustrated during Leg 67 by the recovery of gas hydrate, a safe way to deal with the hydrate was required. It was assumed that the gas hydrate, an icelike substance, might form a seal beneath which free gas is trapped. The free gas could be pressured, and if a hole penetrated the seal a blowout might occur. Thus the Glomar Challenger was not allowed to drill through the level of gas hydrate. The seismic data of the University of Texas was reprocessed to bring out the reflections formed at the base of gas hydrate. These reflections are recognized by their configuration, which simulates the configuration of the seafloor, but are overprinted on the reflective sequence at some depth below it. Sufficient base of gas-hydrate reflections were thus identified to establish this depth with certainty so that it could be projected within the site survey area even where no base of hydrate reflector was observed. In addition, temperature was measured at the ESSO Petrel and Leg 67 drill holes. The general depth of the hydrate reflection could also be predicted from temperature because the stability field of methane gas hydrate recovered on Leg 67 is a function of depth and the temperature gradient. Drilling sites were therefore located safely above the base of the gas hydrate on basement highs.

The second objective of Leg 84 was the study of the origin and occurrence of the gas hydrate in the marine environment. Although hydrate had been drilled on land in the high latitudes, marine gas hydrates had been sampled and studied in limited quantity only on Leg 67 . In addition, a single site on the lower slope off the Nicoya Peninsula of Costa Rica (Site 565) was drilled with the same objectives as those off Guatemala.

\section{GEOPHYSICAL DATA}

Geophysical studies have continued ever since the University of Texas predrilling site survey. Prior to Leg 67 


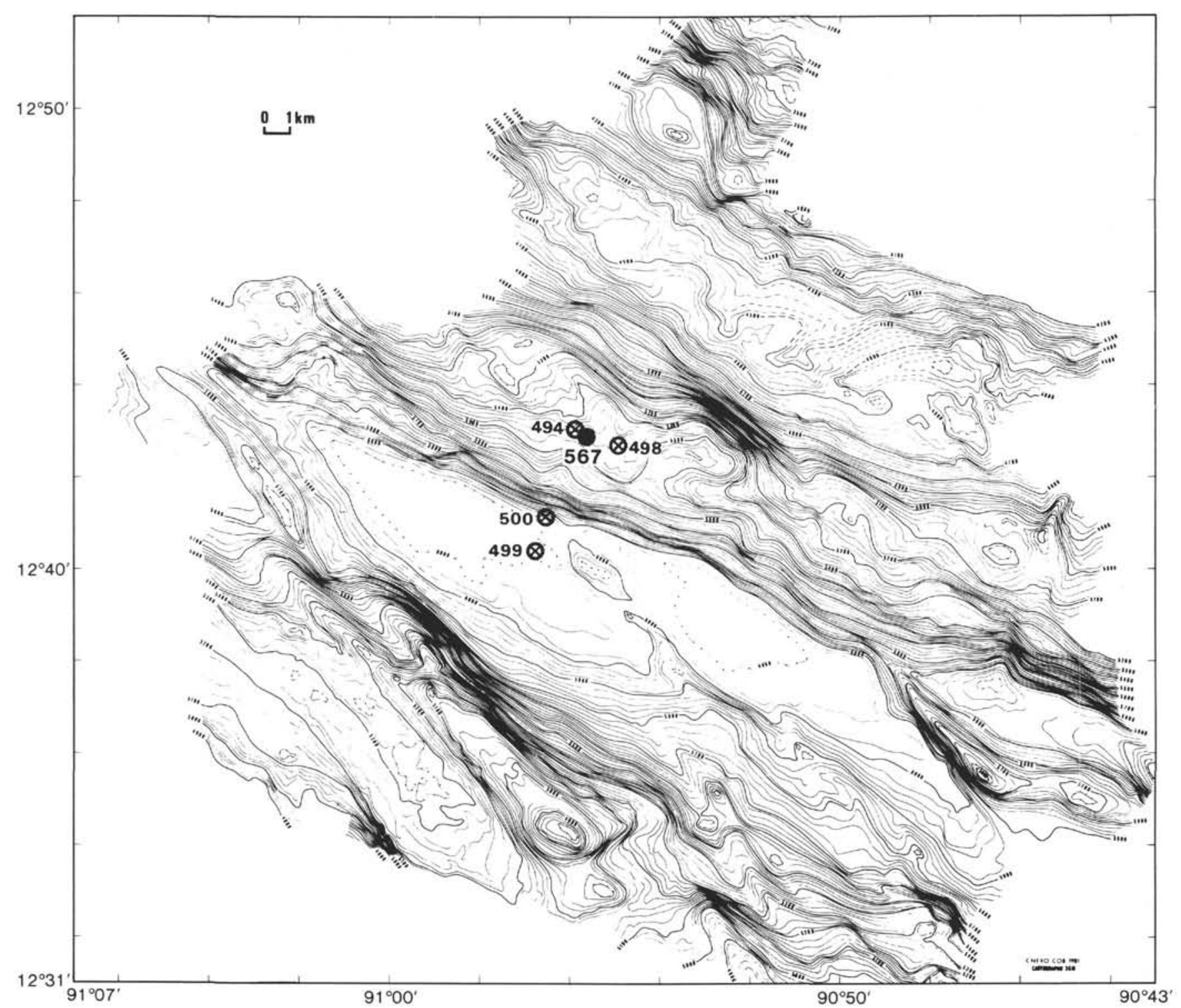

Figure 2. Bathymetric map made with the Seabeam instrument aboard the $J$. Charcot (from Aubouin, Stephan, et al., 1981).

only the University of Texas seismic, magnetic, and OBS (ocean-bottom seismometer) refraction data were available (Ibrahim et al., 1979; Ladd et al., 1982). After Leg 67, a Seabeam survey (Renard et al., 1980; Aubouin, Stephan, et al., 1981) and a deep-tow survey (Moore et al., 1982) were made; and after Leg 84, another Seabeam survey and a high-resolution seismic reflection survey (T. Shipley et al., personal communication, 1983) were made. The seeming inability to predict what would be encountered in the drilling from the initial geophysical data provided impetus for a continuing search for definitive geophysical resolutions.

Topography, especially high-resolution topography as provided by the Seabeam instrument, was used to address the tectonic problems of initial subduction at the base of the landward slope of the Trench, the origin of benches displayed prominently on the main seismic record of the transect, and the nature of the midslope terrace beneath which most of the base of gas-hydrate re- flections were found. From the initial processed seismic records it was obvious that slope sediment covers much of the basement topography. Thus much of the tectonics that configured the basement upper surface could be studied in plain view rather than only in widely spaced profiles.

The initial Seabeam survey made by the Charcot revealed that the Cocos Plate has a structural fabric trending 30 to $35^{\circ}$ to the Trench axis (Renard et al., 1980; Aubouin, Stephan, et al., 1981; Aubouin, Stephan, et al., 1982). This structural fabric governs the trend of horst and graben formed where the Plate is flexed downward into the Trench. Thus the Trench floor is sectioned into a series of diamond-shaped basins separated by ridges (Fig. 2). The basins are graben in the Cocos Plate, and the ridges are horsts. This structure is a consequence of the progressive burial of the Cocos Plate beneath the sediment filling the Trench. This angular relationship between the structural fabric of the Cocos and Carib- 
bean plates contrasts well in the contours of the Seabeam maps. The lowermost landward slope of the Trench is formed by local fault-bounded steps, but the nature of the bounding faults is not clearly revealed in the original seismic records because diffractions obscure structure. The trend of these bounding faults bears little relation to that of the ridges and troughs in the subducting Cocos Plate. The local distribution and irregular topography of the steps were used to argue for normal rather than reverse or thrust fault origin for the benches.

A second Seabeam survey (T. Shipley et al,, personal communication, 1983) extended the area of coverage to include the midslope area and San José Canyon (Fig. 3). The first and second surveys were merged and combined with conventional bathymetric data to provide a block of data for analysis with perspective diagrams (Fig. 4). With the perspective diagrams three topographic divisions of the slope become distinct: the upper slope begins as a sharp break at the edge of the shelf and ends at the smooth gently dipping midslope terrace; the terrace gives way to a lower slope of hummocky morphology terminated at the Trench by a straight basal scarp. In the central part of the mapped area are two benches with irregular surfaces. The benches and bounding scarps are features local to the mapped area in a subtle reentrant and are suggestive of a collapsed slope topography. However, the basal scarp has maintained its linear trace along the Trench axis.

San José Canyon is a prominent transverse feature of the shelf and the slope. The Canyon reaches its maximum 1.8-km depth of erosion as it crosses the shelf edge. Its course is not disrupted by tectonism until it reaches the benches of the lower slope. Drilling at Site 566 indicates a Miocene age for the San José Canyon. From the seismic data and the drilling it is clear that erosion in the Canyon has stripped the basement of its cover near the thalweg. The age of sediment redeposit on the basement is the late Miocene, as indicated at Site 566 (Site 566 report, this volume). The Canyon shows little disruption except at the benches of the lower slope. The morphology and sedimentary record along San José Canyon suggest tectonic stability along the slope since the late Miocene.

Seismic reflection records GUA-13 and -18 , the main records along the transect, were completely reprocessed with programs not available during the original survey (Fig. 5). Diffractions that obscured many tectonic relations in the original site survey data were eliminated by migration. The reprocessed records display the truncation of beds along the scarps bounding the benches of the lower slope; the relation between slope deposits and the basement was clarified locally, and the resolution of beds in the forearc basin and the sediment sequence below it provided not only deeper imaging but also resolution of as little as 100-m vertical displacements along faults, details not visible in the initial site survey data. The greater detail strengthened interpretation and made the geophysical observations more consistent with the drill results.

Sediment of the Neogene forearc basin and the underlying Paleocene and Cretaceous base of continental margin sediment have been little deformed by convergence. The beds are locally broken by faults dipping both landward and seaward with less than $250 \mathrm{~m}$ vertical displacement. Within the reflective sequence are many continuous beds that are interspersed with a few local unconformities and pinching of beds. These irregularities are concentrated on the seaward side of the basin. A reconstruction of the depositional history indicates accumulation of the Cretaceous and Paleocene sediment in a tabular body probably more than $100 \mathrm{~km}$ wide and at rates generally found in terrigenous deposits. The shapes of the overlying Eocene and Oligocene bodies indicate uplift of the front of the margin, and, by the $\mathrm{Ne}$ ogene, a well-defined forearc basin had developed. The southeastern part of the surveyed area was subaerially eroded before the early Miocene and, in a less extensive way, at various times during the Neogene, but the northwestern part appears to have remained more or less submerged. Uplift continued during the Neogene at the edge of the shelf but at a slower rate than during the Eocene and Oligocene. At the same time, the forearc basin subsided until at its center basement may now be deeper than $10 \mathrm{~km}$. The most active tectonism was at the edge of the shelf and was not a regional event that involved the whole forearc area. Therefore the general tectonic history developed by Seely (1979) from a paleontological summary of the ESSO Petrel drill hole is confirmed for the forearc by a regional analysis of seismic stratigraphy. But this history does not fully apply to the landward slope of the Trench. The tectonic histories of the shelf and the landward slope were diverse in the pre-Eocene. A fundamental tectonic boundary separates a Cretaceous-Paleocene sedimentary section on the shelf from another on the slope and each seems to have developed in a different environment. Displacement on the upper slope boundary juxtaposed these rocks just before or during the tectonic episode that initiated development of the present arc-trench system. The present system began to form in the Eocene and by the late Oligocene it had become structured much like it is at present.

One of the last tectonic events was the failure of the lower slope, as recognized by Aubouin, Stephan et al. (1981). The slope is underlain by an altered ophiolitic basement that failed and thus produced two rough benches. Such failure suggests little transmission of compressive horizontal stress into the upper plate. The high degree of decoupling across the subduction zone suggested by the low compressive strain is consistent with the overpressured pore fluids observed directly on Leg 84 . The contrast between the collapse morphology of the benches and the straight escarpment at the Trench axis emphasizes the passive origin of the benches and the dynamic process by which the Trench axis maintains its position. The slope sediment structure and the longevity of San José Canyon show that only the front of the margin and the edge of the shelf appear to be subject to rapid tectonism.

The margin off Guatemala has been surveyed extensively with refraction seismic techniques including two OBS surveys. The first was done during the site survey and was reported by Ibrahim et al. (1979), and the sec- 


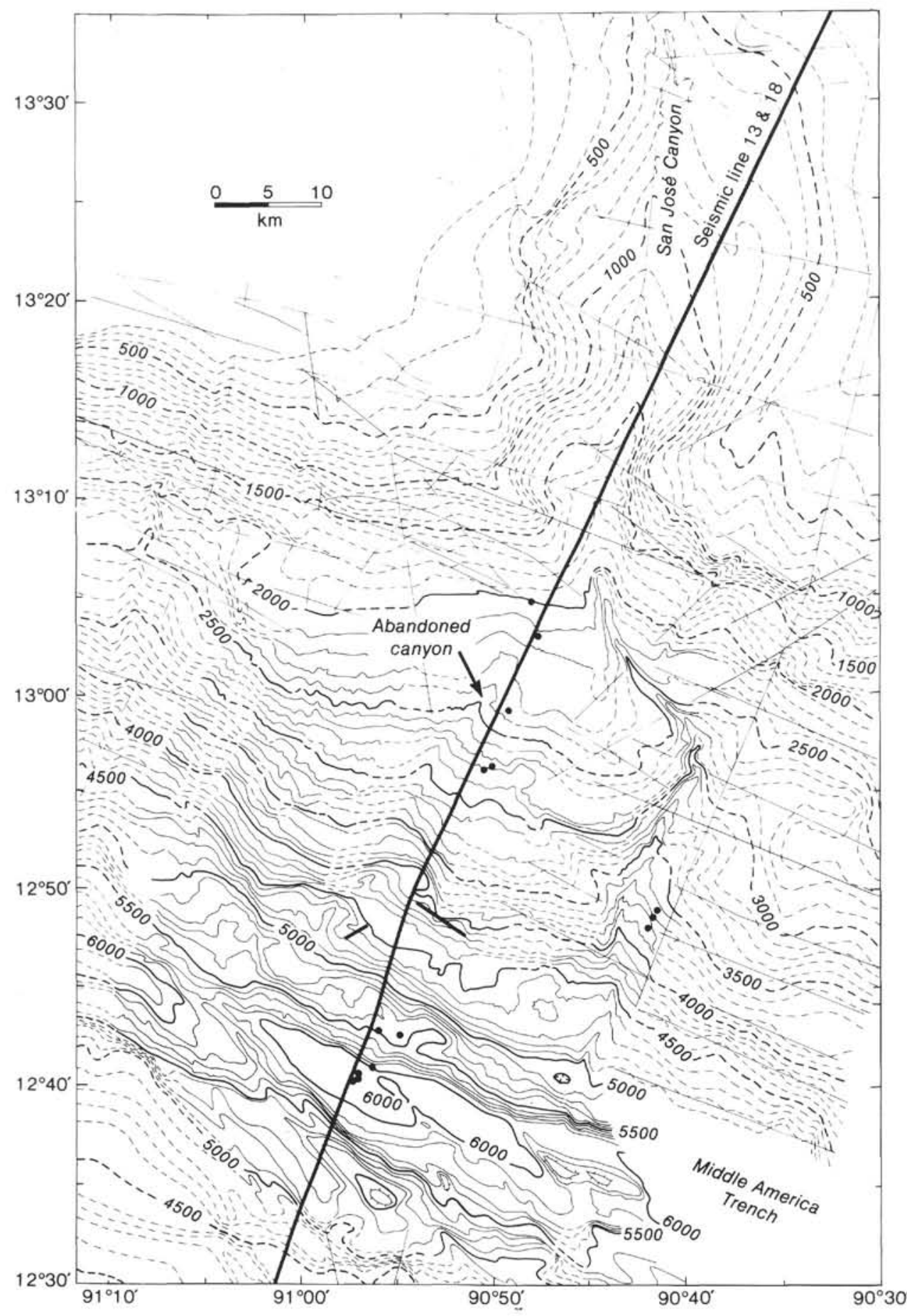

Figure 3. Topography across the DSDP Middle America Trench transect area. Contours, at 100-m intervals, are solid where controlled by Seabeam data (Aubouin, Stephan, et al., 1981; T. H. Shipley et al., personal communication, 1983), and are dashed where controlled by conventional soundings. Lines are adjusted ships tracks of conventional data and the regular grid of tracks at the right margin are from the Glomar Challenger, made during a standby period. Conventional data positions were adjusted by fitting conventional bathymetric profiles to the Seabeam data in areas of overlap. The track through the center of the map is GUA-13 and -18, dots are DSDP drill sites, and lines are dredge tracks from the pre-drilling survey (see von Huene et al., this volume).

ond was done during Leg 67 and is reported here (Ambos and Hussong, this volume). The rocks comprising this margin have relatively low acoustic velocities and few strong magnetic anomalies. The weathered igneous ocean crust that comprises this margin has low acoustic velocity and magnetic susceptibility. Thus geophysical methods are poorly suited to clearly differentiate consolidated and tectonized sediment from igneous oceanic crust. The acoustic velocity of the igneous oceanic crust off Guatemala is in the same range as that of the Creta- 


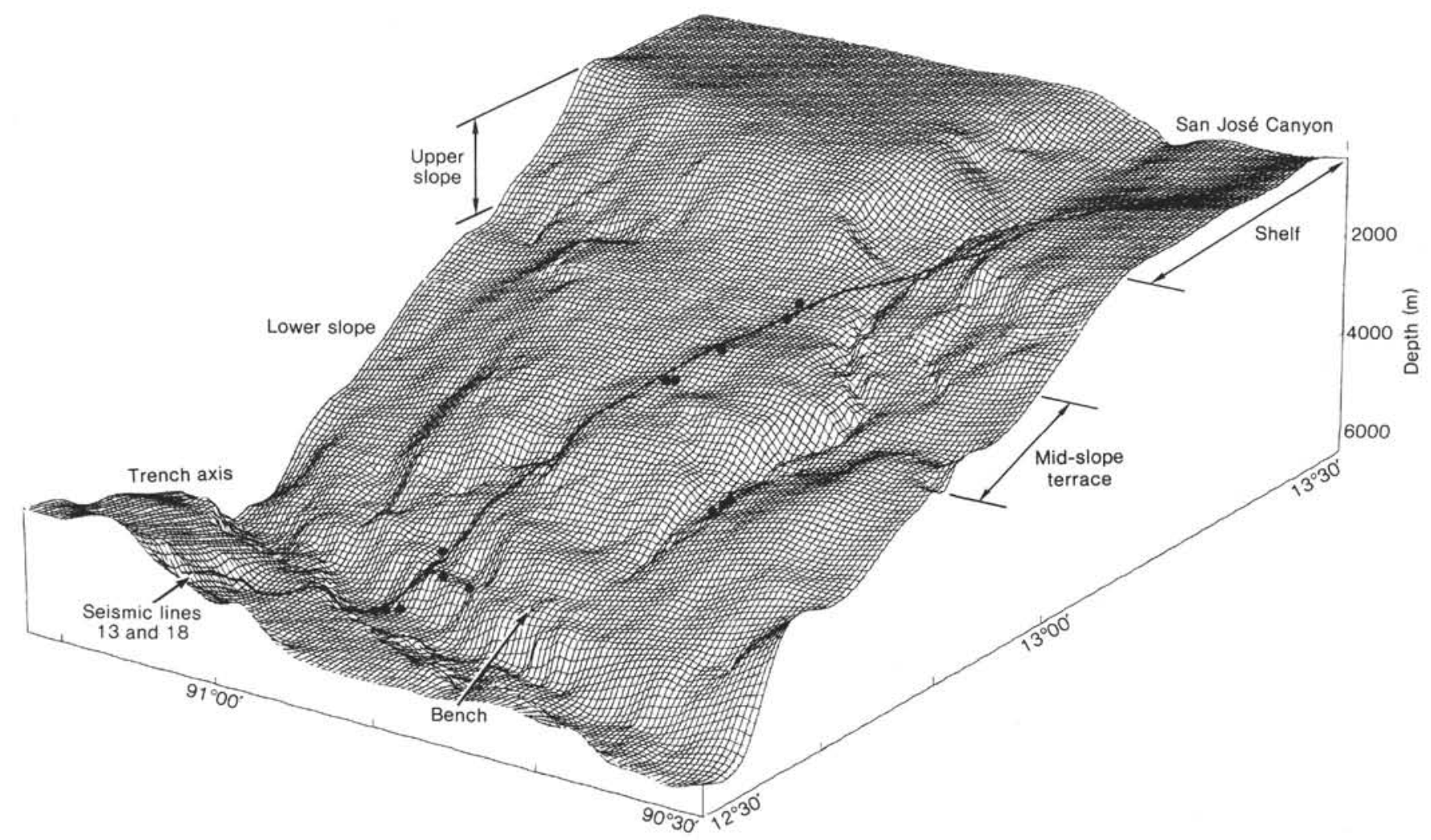

Figure 4. Perspective diagram of the bathymetry in Figure 2 at an exaggeration of $\times 7.5$.

ceous limestone recovered at Site 567 or the Cretaceous shale recovered from beneath the Japan Trench margin (Murauchi and Ludwig, 1980).

The experiences of Legs 67 and 84 show the level of interpretive constraint even with gridded geophysical surveys and modern techniques. Resolution in seismic reflection records is poor in deep water and along steep slopes because many of the assumptions in the seismic technique are violated. The original site survey provided such loose constraints that major tectonic features were misinterpreted. In hindsight, the Seabeam topography, deep-tow surveying, a well-processed seismic reflection survey, and a good map of magnetic anomalies would have indicated the lack of a classical accretionary structure. However, a single multichannel seismic record across the margin, magnetic anomalies, gravity anomalies, and reconnaissance bathymetry provide insufficient data to identify a nonaccretionary origin of the Guatemalan margin. The drilling that showed the existence of a pre-Eocene or even pre-Late Cretaceous basement everywhere beneath the slope is an even better argument. Nevertheless, until a more detailed survey is done along the record published by Seely et al. (1974), it is still possible that within a generally nonaccretionary margin, local accretion has been occurring at the foot of the slope.

\section{SEDIMENTARY ROCKS}

\section{Upper Oligocene to Quaternary}

Most of the sediment recovered during Leg 84 was slope sediment; when considered together with the slope deposits recovered on Leg 67, the five sites and nine cored holes represent the greatest amount of such material collected from drilled holes along any IPOD active margin transect (Fig. 6). The sampled material is partially from an area of detailed Seabeam bathymetry and within a grid of seismic data. The sediment sources were from land, and as sea level lowered, from local insular areas at the edge of the shelf and along the coast. The clastic sediment was transported by channels of various sizes that shifted location with time. Thus as one depocenter was accumulating sediment rapidly, another may have lost its feeder channel and temporarily have been in an interchannel area where hemipelagic sedimentation was dominant, or perhaps even in an erosional area where material was removed to produce a local unconformity. Where the slope was steep, downslope transport and a variety of mass transported materials were deposited along local topographic flats, benches, or ultimately in the Trench. Thus we recognized no simple lithofacies distinction between deposits in slope basins and in the Trench off Guatemala.

The observations on which we base this general model are from the study of core, seismic, and bathymetric information. Although the main sediment type recovered is hemipelagic mud and mudstone, considerable sand and calcareous mudstone were also recovered. In some sections the amount of sand, including coarse sand, exceeded that found in the Trench (Coulbourn et al., 1982). Along San José Canyon, sand included rock fragments from the arc and from the basement that floors parts of the Canyon; transport through San José Canyon is particularly rapid and involves materials that have traveled comparatively little since leaving the land. Some stretches 

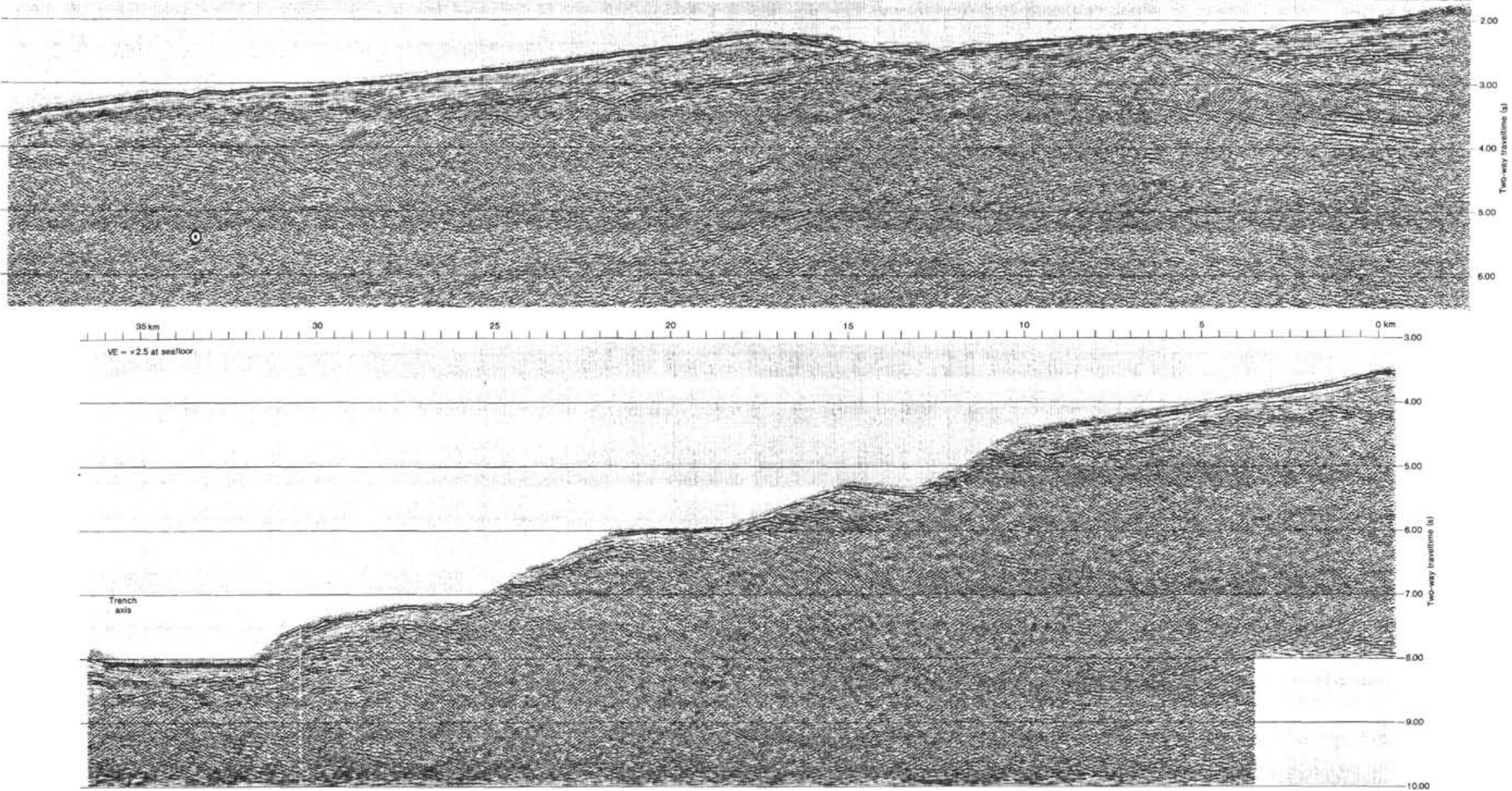

Figure 5. Seismic record GUA-13, landward slope of the Middle America Trench, Guatemala, migrated time section. 


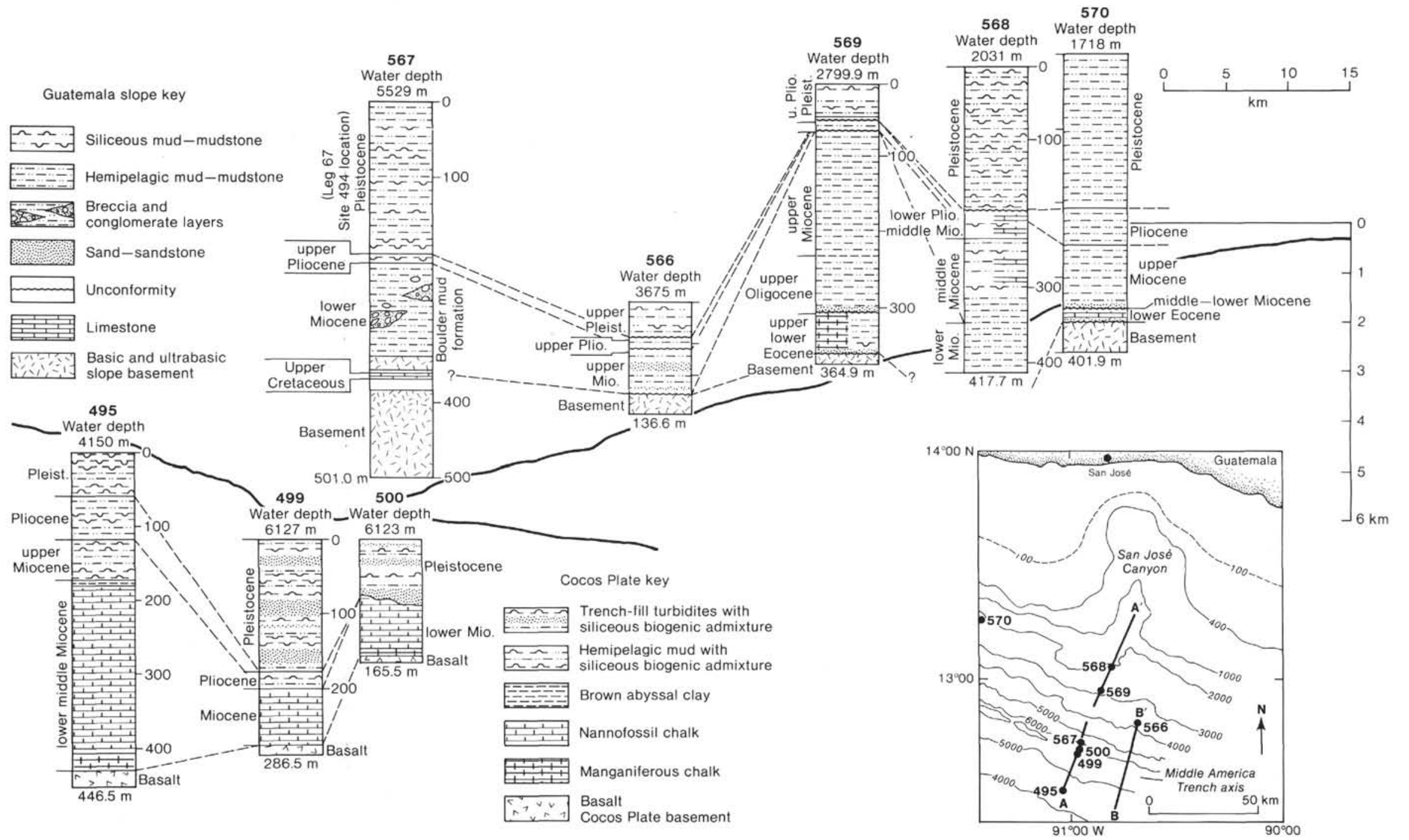

Figure 6. Simplified stratigraphic columns summarizing the results of Legs 67 and 84 . Note that the oceanic plate, the Trench floor, and the continental margin were drilled to their basement. A notable feature is the presence of the pre-early Eocene (Sites 569, 570), pre-Late Cretaceous basement (Site 567) on the slope, namely at the very toe, which disagrees with the accretionary model. 
of the Canyon have overbank deposits, others are eroded, and the upper reaches are marked by a sharp Vshaped thalweg. A possible abandoned channel of San José Canyon (von Huene, Miller, et al., this volume) suggests that tectonism not only causes small channels to shift, but also causes large canyons to shift position and depocenters with time. San José Canyon ends at the benches of the lower slope, and, seen with Seabeam data, its channel cannot be traced through this area of tectonic disturbance. Thus San José Canyon is probably older than the benches.

Contrasting in size with San José Canyon are the many smaller channels in the Seabeam data or in seismic or bathymetric records that run parallel to the regional trend. Sharp V-shaped rills are seen in the records with a high vertical exaggeration. Some begin and end in a short distance on the slope, others are tributaries of large channels or an integrated channel network. The short segments may be part of abandoned channels.

In addition to sediment transport in channels are the downslope mass movements shown by displaced fossils. All depth diagnostic microfossil assemblages are mostly displaced from upslope. A general creep of the cover of slope deposits seems to prevail except on local benches or terraces. More catastrophic are the thick (ca. 50-m) Miocene boulder breccias near the present base of the slope that may be from slumping or perhaps from accretion of sediment represented by the extensive reflective horizons in seismic records across the slope.

Sediment accumulation rates are variable. At some sites sediment accumulates at rates of $300 \mathrm{~m} / \mathrm{m}$.y. and more, above a long hiatus or unconformity. Many channels appear to have supplied sediment to one depocenter for 2 to 5 m.y. and then to have shifted course. Erosion is well documented along the length of San José Canyon. The lengthy period of sustained slope deposition at Site 570, for instance, provides a quantitative indication of tectonic stability during which channels and a depocenter remained undisrupted.

The large middle and late Miocene hiatus in the slope sediment cover at Sites 567, 568, and 569 may have been caused by bottom-water currents or by erosion along an abandoned channel of San José Canyon. Stone and Keller, and McDougall (both this volume) point out the corresponding general Pacific Miocene hiatuses and the detection of changing bottom waters in the benthic fauna. However, the large abandoned canyon in the Seabeam bathymetry (von Huene, this volume) suggests downslope erosion in the vicinity of the sites, which is another possible mechanism. No distinct unconformity was noted in seismic records corresponding to the hiatus, and at Sites 568 and 495 (Leg 67) the hiatus appeared to correspond to a change in sedimentation. Thus the relative importance of different erosional processes is difficult to assess along the IPOD Guatemalan transect.

\section{Late Cretaceous to Eocene}

The few cores in which Late Cretaceous and Eocene sediment was recovered are very significant because in some cases they represent the only examples of the East
Pacific open ocean and lower continental slope stratigraphy preserved in Central America (Fig. 6). Two distinct Eocene domains can be recognized. Landward under the shelf is a basin with a thick clastic sediment section documented at the Esso Petrel Well and traced over an extensive area in seismic records. The limestones, sandstones, and black and red conglomerates recovered at Site 570 may represent distal equivalents of this facies that rest directly on a basement high in the vicinity of the shelf edge as seen in seismic records. Seaward, beneath the middle and lower slope is a deep open ocean sequence represented by dark gray siliceous mudstones deposited below the CCD (Sites 494 and 569). These are not slope deposits but have ocean plate affinities.

The same distinction between environments is indicated in the upper Campanian to Maestrichtian sedimentary rocks. Beneath the shelf is a thick base of slope clastic sediment section whereas beneath the slope are thin pelagic limestones deposited above the CCD away from any terrigenous influence. These two distinct environments may extend along much of the Middle America Trench slope and shelf from the Gulf of Tehuantepec to the Nicoya Peninsula.

Far less clear is the tectonic history that gave rise to the present juxtaposition of these depositional environments. Was the Eocene basin bounded seaward by a chain of islands in the vicinity of the present shelf edge? Simple reconstruction of the Eocene basin edge in the northern part of the IPOD transect area indicates such islands, and the Nicoya Peninsula was also insular at the time. What were the Cretaceous and Eocene morphological and tectonic environments seaward of the basin? The scant litho- and biostratigraphy suggest Cretaceous deposition far from a continent and the Eocene rocks, although deposited in deeper water, received distal terrigenous material. Would the apparent deepening between the Cretaceous (above the CCD) and Eocene (below the CCD) represent the approach of an oceanic plate toward land? A similar but continuous sequence was recovered in the Neogene on the Cocos Plate, documenting the transit of the Plate toward the Middle America Trench (Aubouin, von Huene et al., 1982). What was the character of the Paleocene tectonic event that uplifted the inshore basin and juxtaposed a terrain of oceanic affinity against it? The constraints are insufficient to favor an environment dominated by either transcurrent or convergent motions.

These questions, crucial for the interpretation of Central American tectonic history, serve as directions for further research.

\section{IGNEOUS ROCKS}

The acoustic basement of the Middle America Trench landward slope was recovered at four sites drilled during Leg 84 (Fig. 6). Harzburgites (cumulative-texture peridotites), gabbros, dolerites, basalts, and amphibolite facies rocks were recognized by petrologic, $\mathrm{X}$-ray fluorescence, and microprobe analyses. Some of these rocks belong to an ophiolitic sequence. A few basalt samples have also been studied with ${ }^{40} \mathrm{~K}-{ }^{40} \mathrm{Ar}$ isotopic ratios (Bellon et al., this volume). 
The ultramafic rocks were sampled from Holes 567A, $566,566 \mathrm{~A}, 566 \mathrm{C}$, and 570 . In Hole 567 A the ultramafic rocks are in three distinct positions: (1) reworked serpentine blocks and pebbles in the lower Miocene sediments, between 260 and $330 \mathrm{~m}$; (2) a thick block of serpentinized peridotites above the Upper Cretaceous limestones; and (3) between 380 and $500 \mathrm{~m}$-recovered basement rocks under the Upper Cretaceous limestones.

All the ultramafic rocks recovered during Leg 84 are widely serpentinized, however, their primary mineralogy appears as relicts in some samples. Because the serpentinization of the pyroxene is different from that of olivine, it was possible to identify the original textures. Thus two groups of ultramafic rocks were identified: (1) peridotites (harzburgites) with a xenomorphic texture (Holes $567 \mathrm{~A}, 566$, and $566 \mathrm{C}$ ) that is generally serpentinized compose the first group. (The olivines are $\mathrm{Fo}_{88}-\mathrm{FO}_{92}$ and the orthopyroxenes are $\mathrm{En}_{86}-\mathrm{En}_{89}$, the clinopyroxene chemical compositions are Wo $=47.9, \mathrm{En}=48.4$, Fs $=3.7$, and from one sample to another clinopyroxenes show obvious variations in $\mathrm{Al}$ and $\mathrm{Ca}$ contents. The spinels have a positive correlation between $\mathrm{Cr} / \mathrm{Al}$ and $\mathrm{Mg}$ / $\mathrm{Fe}$ ratios. The rocks and the mineralogical chemical compositions of Leg 84 harzburgites are similar to those of many ophiolitic complexes, for example, from Troodos and from Oman.) (2) The second group of ultramafic rocks comprises cumulative-texture peridotites that were recovered at Site 570. (The olivine appears in automorphic crystal aggregates cemented by xenomorphic pyroxene. The olivine and the pyroxene are completely serpentinized, but the cumulative texture is still obvious.)

Gabbro, recovered only in Hole 567A, is mainly composed of plagioclase, green amphibole, and occasional clinopyroxene. The paragenesis is: (1) plagioclase + clinopyroxene + pseudomorph orthopyroxene; (2) plagioclase + clinopyroxene + amphibole. Opaque minerals are absent. Magmatic layering is obvious in one sample. The chemical compositions of the clinopyroxene $\left(\mathrm{Wo}_{44}\right.$, $\left.\mathrm{En}_{45}, \mathrm{Fs}_{10}\right)$ and plagioclase $\left(\mathrm{An}_{86-76}\right)$ resemble those of Oman and Antalya ophiolites.

Dolerite, recovered from several levels of Hole 567A, has a homogeneous chemical composition that shows high $\mathrm{Mg}-\mathrm{Fe}$ and $\mathrm{Ti}$ contents and low concentrations of $\mathrm{K}$. The clinopyroxene is calcic and zoned, the plagioclase is $\mathrm{An}_{80}$ to $\mathrm{An}_{40}$, the opaque minerals are ilmenite and titanomagnetite. The dolerite has tholeitic affinities.

Basalt was only recovered from the basement of Hole 567A. One sample $(567 \mathrm{~A}-19, \mathrm{CC})$ gives an age of 78.7 $+/-3.9$ m.y. No major secondary processes have been detected in this basalt that suggest the ${ }^{40} \mathrm{~K}-{ }^{40} \mathrm{Ar}$ age may reflect the true crystallization age of this lava. This age is in good agreement with the stratigraphic position of the sample just under the upper Campanian-lower Maestrichtian limestones, that is to say around $72.1 \mathrm{~m}$.y. This sample is a quartz normative basalt with low $\mathrm{TiO}_{2}$ and high $\mathrm{Al}_{2} \mathrm{O}_{3}$ contents. Its major element geochemistry is very similar to that of the andesites and basalts recovered from the same stratigraphic level during Leg 67 (Hole 494A). The trace elements analysis shows low amounts of $\mathrm{Cr}, \mathrm{Ni}, \mathrm{Sr}, \mathrm{Zr}, \mathrm{Ba}$, and hydromagmaphile elements. The ratio $\mathrm{Ti} / \mathrm{V}$ is in the orogenic lava field according to Shervais (1982). The trace element contents are nearly identical to those of the samples from Hole 494A. The pyroxenes from Sample 567A-19,CC have high $\mathrm{Mg} / \mathrm{Fe}$ ratios, and high $\mathrm{SiO}_{2}$ and low $\mathrm{AlO}_{3}$ and $\mathrm{TiO}_{2}$ contents. In the discrimination diagram $(\mathrm{Ti} / \mathrm{Ca}+$ $\mathrm{Na}$ ) proposed by Leterrier et al. (1982), samples plot into the orogenic basalt field. The plagioclases are $\mathrm{An}_{72}$ to $\mathrm{An}_{50}$ and do not contain significant amounts of $\mathrm{K}_{2} \mathrm{O}$ and $\mathrm{MgO}$. Thus Sample 567A-19,CC shows mineralogical and geochemical characteristics similar to those of the basalt from Hole 494A that provide evidence for an active volcanic island arc during the Santonian and early Campanian.

Four other samples from Hole 567A were also studied. They are clearly different from the 567A-19,CC orogenic basalt and from oceanic basalts from the Cocos Plate. These rocks show an enrichment in light rare earths, high $\mathrm{Ba}$ and $\mathrm{Sr}$ contents, and a wealth in $\mathrm{Ti}$ and normative nepheline. On the other hand, the pyroxenes and plagioclases are typical of alkaline basalts. Three ${ }^{40} \mathrm{~K}$ ${ }^{40} \mathrm{Ar}$ ages were obtained: (1) the youngest is $91+/-4.5$ m.y. from Sample 567A-29-2, 147-149 cm; (2) the second is $132+/-6.6$ m.y. from Sample 567A-25-3, 74-78 $\mathrm{cm}$; (3) the oldest, from Sample 567A-25-2, 90-96 cm, is $169+/-8.4$ m.y. The oldest radiometric age is obtained from the basalt that has the less developed secondary paragenesis, that is to say, the oldest age seems to be the nearest to the true crystallization age.

Thus a significant difference was observed between the orogenic basalt ages that are young and the alkaline basalt ages that are significantly older. At the moment these oldest ages (132-168 m.y.) must be considered with care; in particular they must be compared with the onshore Costa Rican ophiolitic complex of the Santa Elena Peninsula and the Santa Clara ophiolitic complex of Guatemala. As a matter of fact, potassic alkaline rocks of the lower structural unit of the Santa Elena complex give radiometric ages of 130-140 m.y., and fossils in sedimentary inclusions in pillow basalts of the Santa Clara ophiolitic complex of Guatemala yield an age range of 100 to 141 m.y.

Amphibolites. Hole 569A encountered metamorphic basement at a depth of $350 \mathrm{~m}$ beneath the seafloor covered by lower Eocene sediments. Only $2 \mathrm{~m}$ of metamorphic rocks were recovered in Cores 10 and 11. All of these rocks are amphibolites, with evidence of low-temperature retrograde metamorphism in the greenschist facies. But the primary high-temperature paragenesis (magnesiohornblende, basic plagioclase, ilmenite) of amphibolite facies is partially preserved. The $\mathrm{SiO}_{2}, \mathrm{Al}_{2} \mathrm{O}_{3}, \mathrm{FeO}$, $\mathrm{MgO}$, and $\mathrm{TiO}$ contents of these amphibolites are those of basalts. The $\mathrm{K}_{2} \mathrm{O}$ content is very low and suggests tholeiitic affinities. The $\mathrm{Na}_{2} \mathrm{O}$ content is very high and thus the amphibolites of Hole 569A may correspond to tholeiitic basalts.

\section{Summary-Igneous Rocks}

From the drilling of Leg 84, igneous basement was found to consist of mafic and ultramafic rocks includ- 
ing basalt, dolerites, gabbros, and peridotites and rocks of metamorphic-grade amphibolite facies. The harzburgites and the ultramafic cumulates may be linked to the same ophiolitic complex as the gabbros because of their magmatic layering, their weak $\mathrm{Fe}$ and $\mathrm{Ti}$ contents, and the lack of opaque minerals. The dolerites and the basalts differ from the gabbros by their chemical composition, their $\mathrm{Fe}$ and $\mathrm{Ti}$ contents, and the mineralogical evolution of the clinopyroxenes and plagioclases. The amphibolites of Hole 569A are high-temperature metamorphic rocks. Such rocks are sometimes found associated with ophiolitic complexes as a tectonic sole under or inside the ophiolitic complexes. Thus the basement rock of the landward slope of the Middle America Trench off Guatemala could be a disrupted ophiolitic complex, except for the basalts in Sample 567A-19,CC, which could be linked to a volcanic island arc.

Ophiolite outcrops appear on land in Central America. They are linked to the Polochic-Motagua zone of Guatemala and crop out in the Santa Elena Peninsula of Costa Rica. These two outcrops of mafic and ultramafic rocks have the following similarities with the drilled basement of the landward slope of the Middle America Trench off Guatemala: (1) the major component is harzburgites; (2) the plutonic rocks are ultramafic cumulates and layered gabbros; (3) they include basalts, dolerites, and amphibolites; and (4) the lower Eocene-Upper Cretaceous sediments overlie the ophiolites.

This interpretation of basement rocks as part of an ophiolitic complex is supported by radiometric $\left({ }^{40} \mathrm{~K}-{ }^{40} \mathrm{Ar}\right)$ data that indicate a Mesozoic age for the igneous basement-at least pre-Late Cretaceous (pre-Turonian, 91 m.y.) or at most pre-Late Jurassic (pre-Callovian, 168 m.y.). The igneous basement of Central America is old; its formation is certainly unrelated to Neogene accretion.

\section{BIOSTRATIGRAPHY AND PALEOENVIRONMENT}

Microfossil assemblages recovered on Leg 84 include foraminifers, nannoflora, radiolarians, diatoms, and pollen that ranged from Late Cretaceous to Holocene. The sparse Cretaceous record consists of an Albian-Aptian radiolarian assemblage in chert, and a Maestrichtian foraminiferal and nannoflora assemblage in deep-water limestone. This fragmental Mesozoic record was recovered in dredge samples and in 2 drill holes (494A, Leg $67 ; 567 \mathrm{~A}$, Leg 84); at 3 sites on the slope where drilling penetrated to the basement the Mesozoic was absent.

Paleogene sediment was also discontinuous and thinner than that of the Neogene, and it was broken by local unconformities or hiatuses. No Paleocene was recovered from the slope despite the thick Paleocene section at the edge of the shelf (Seeley, 1979). The Eocene and Oligocene sections were present but incomplete at Sites 569 and 570, and at Sites 556 and 567 the entire Paleogene was missing. However, the discontinuity of the Paleogene sediment was probably overestimated by the selection of drill sites on basement highs.

Neogene sequences, although more continuous than the older ones, were also broken by hiatuses and a single large unconformity. Along the main transect of drill holes, the planktonic foraminiferal biostratigraphy in particular indicates absence of the middle Miocene (Sites 567, 568, 569; and Leg 67 Sites 494 and 496). Elsewhere, away from the main transect as at site 570 , the middle Miocene sequence is relatively complete. Local erosion in the transect area is a possible explanation, because San José Canyon has been eroding its present course since at least the late Miocene and its predecessor was probably the abandoned channel parallel to the transect of drill holes. The abandoned channel was not apparent until the Seabeam survey of the middle slope. If this is true, the abandoned channel eroded much of the middle and lower Miocene section during the late Miocene and was beheaded during the late Miocene and the Pliocene when its trace across the upper slope tectonic zone was disrupted by tectonism.

Abundant microfossils and broad species diversity resulted in very good biostratigraphic resolution. At no site was a biostratigraphic zone repeated by thrust faulting, and the Eocene to Holocene section was drilled in normal succession at all sites.

The environments of deposition are particularly well indicated by the benthic foraminifers. So far as the modern assemblages show, the fauna on the slope are characterized by downslope movement with most of the assemblages being transported from upslope. The oceanic and shelf assemblages on the other hand are characterized by few transported forms and are shallow or deep assemblages. Applying the modern analogy to the ancient sediment indicates a continuous slope paleoenvironment back to the Eocene except at Site 494 (Leg 67), where the Eocene is composed of terrigenous lithologies but does not have the transported fauna. All Cretaceous fauna have open ocean lithostratigraphies and biostratigraphies.

The quantitative analysis of up to 60 benthic foraminiferal species per sample (McDougall, this volume), indicates both the paleodepth and also the identity of water masses along the Guatemalan slope during the Neogene. The paleodepths indicate little vertical change throughout the Neogene within the 1500-m-thick zones that can be distinguished by benthic assemblages. Sites at the base of the slope $(5000 \mathrm{~m})$ show only abyssal benthic assemblages from $3500-2000 \mathrm{~m}$ and have generally remained in that depth range. Sites in the lower and midslope area were at abyssal depths until the PliocenePleistocene when they were uplifted to their present depths at the top of that depth zone (Site 568, and Leg 67 Site 496). Site 570 rose from abyssal depths through the lower bathyal to its present middle bathyal depth in the Pliocene and Pleistocene.

During the Neogene, changes in the depths and compositions of water masses flowing by the Guatemalan slope caused periods of dissolution and changes in faunal composition. The shifting water masses first show the increasingly restricted communication between the Caribbean and the Pacific deep water masses during the middle Miocene; gradually the shallower water masses were affected until establishment of the present circulation system in the Pliocene and Pleistocene. The history of these shifts show superposition of the effects of the 
emergence of Panama on the Antarctic refrigeration and development of Antarctic bottom waters. Pleistocene glaciation and interglacial periods are seen in the pollen record by the spread of conifer forests in the lowland areas interspersed with flora typical of dry but not savanna vegetation.

A major void in the IPOD biostratigraphy of the Central American margin is the absence of a stratigraphy at the edge of the shelf. The drilling of a site in the San José Canyon at the edge of the shelf was planned as the last hole of the leg. However, the time allotted to drilling at this site was required instead to transit to a U.S. port for replacement of the $5000 \mathrm{~m}$ of drill string lost at Site 567. In the decade since the ESSO Petrel hole was drilled at the edge of the shelf, progress in biostratigraphic analysis has reached a higher level of refinement and the use of cores rather than drill cuttings adds further to the precision of results. Thus the suggested $1000-\mathrm{m}$ uplift during the Pliocene-Pleistocene based on the differences in paleobathymetry at the ESSO drill hole and just 20 $\mathrm{km}$ away at Site 570 do not necessitate a corresponding vertical offset along the upper slope tectonic zone. The tectonic and the biostratigraphic value of a core from the edge of the shelf has greatly increased since the Guatemalan transect was first proposed.

\section{STRUCTURAL FEATURES IN CORES}

Tectonic features observed in the cores include those in the ophiolitic basement and those in the overlying sediment. Some of these small features can be related to the more general tectonics of the margin through the techniques developed for the analysis of microstructures.

The ophiolitic rocks have two types of foliation: one developed from magmatic processes during emplacement and the other developed during deformation and alteration of the rock. Primary foliation from magmatic processes can be seen in the ultramafic rock recovered at shallow depths in cores from Site 566. Secondary foliation from deformation can be seen in the foliation of serpentinite throughout the Site 567 section. The foliation and superposition of various igneous rocks from different levels indicates there was intense and complex deformation of the whole section at the front of the margin. In addition to the fragmentation and rotation observed, there is evidence of injection of ductile materials during the shearing, as suggested by the intense deformation of the alkali basalt drilled at the base of the hole at Site 567 (Ogawa et al., this volume). Texturally, the peridotites drilled at Site 570 differ from those at other sites and, despite massive serpentinization, the cumulative texture is still obviously different from the tectonized harzburgites of Site 567 .

Within the massive muddy sediment overlying the igneous basement, vein structure develops from the escape of water through these impervious sediments as they become compacted during burial. These vein structures have been observed in the hemipelagic cover of most modern margins drilled by DSDP. Cowan (1982) described the dark sigmoidal veins spaced from one to several millimeters apart observed during Leg 67. Ogawa et al. and Helm and Volbrecht (both this volume) found the vein filling to contain the same clay minerals as in the adjacent sediment. The fabric of the vein was, however, characterized by fine-grained and closely packed aggregates of clay flakes oriented preferentially parallel to the vein boundaries. The dilational component of displacement perpendicular to the boundaries is evident from the filling of the veins.

The orientation of the shear zones in conjugate sets indicates coaxial deformation with the axis of maximum shortening in a subvertical direction. Therefore the shears could be related to overburden pressure and downslope creep. These shears could also be related to large-scale slumping. The shears appear to be Riedel shears, and there is no indication of low-angle synthetic Riedel shears.

\section{GAS HYDRATE}

During Leg 67 gas hydrates were found unexpectedly at three sites; because the base of the hydrate layer was not known, drilling could not continue to targeted depths. With subsequent geophysical studies, the base of gas hy-drate was determined, and further investigation of the hydrate became a major objective during Leg 84 (Kvenvolden et al., this volume).

On Leg 84 gas hydrates were observed visually at Sites 565,568 , and 570 and inferred to be present, on the basis of inorganic and organic geochemical evidence, at Sites 566 and 569; no evidence of gas hydrates was observed at Site 567. Recovered gas hydrates were solid pieces of white, icelike material occupying fractures in mudstone or pores in sandy lithic ash (Fig. 7). A 1.05m-long core of massive gas hydrate was unexpectedly obtained at Site 570. Downhole logging indicated that the hydrate was actually 3 to $4 \mathrm{~m}$ thick (Mathews and von Huene, this volume), but no sign of this hydrate accumulation could be seen on multichannel or high-resolution single-channel seismic records. The base of the sediment in this area is shallower than the depth to the base of the gas-hydrate zone, and so the base of hydrate reflection was not visible.

The volume of methane released during the decomposition of the samples clearly showed that gas hydrates had been found. The distribution of evolved hydrocarbon gases indicated that structure I gas hydrates were present because of the apparent inclusion of methane and ethane and exclusion of propane and higher molecule weight gases. The water composing gas hydrates was fresh, having chlorinities ranging from 0.5 to $3.2 \%$. At Sites 565, 568, and 570, where gas hydrates were observed visually in cores, the chlorinity of pore water squeezed from sediment decreased with sediment depth. The chlorinity profiles may indicate that gas hydrates not visible in cores can nonetheless occur as finely dispersed small inclusions in sediments. The gas hydrates are not visually observed because of their small size or because they did not survive the drilling and recovery process. This observation is supported by studies of downhole logging (Fig. 8). The velocity and resistivity logs were calibrated in the zone of massive hydrate; when this calibration is applied to other logged sections of the drill hole, it appears that gas hydrate is generally present in concentrations of less than $10 \%$ (Mathews and von 
A

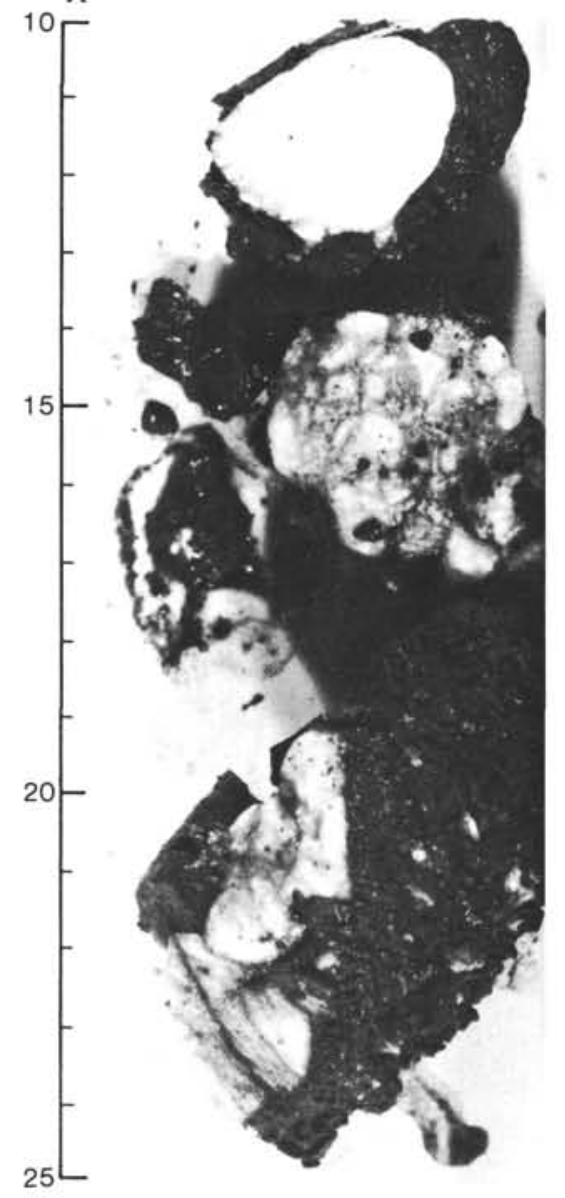

B

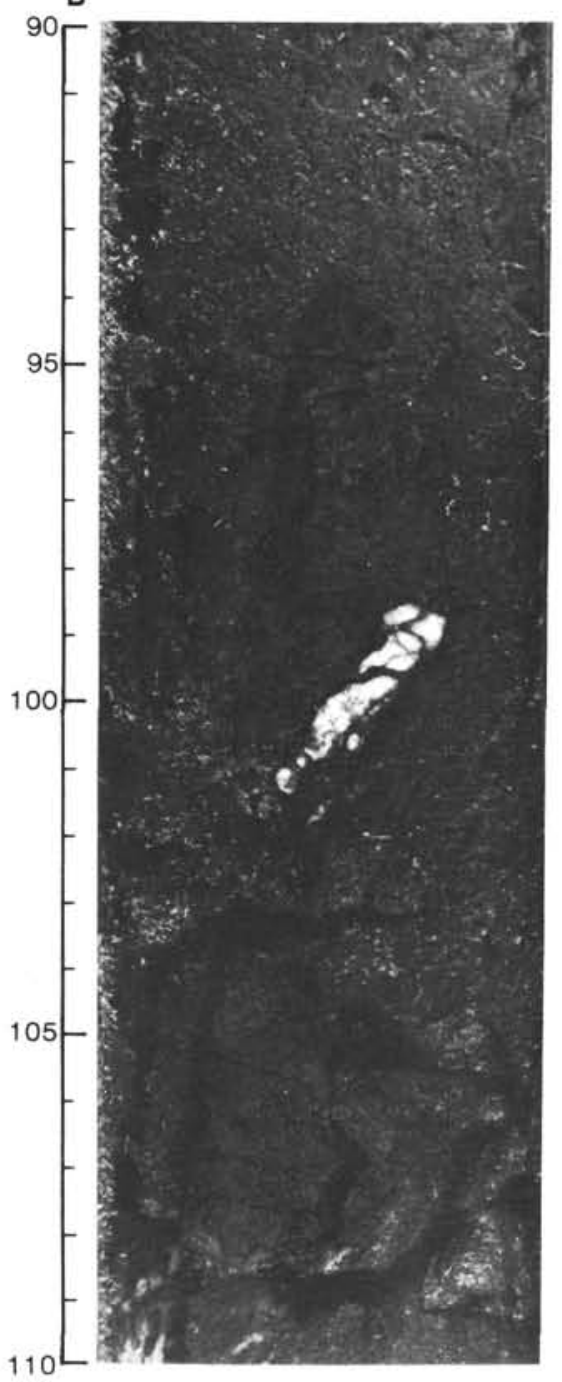

C

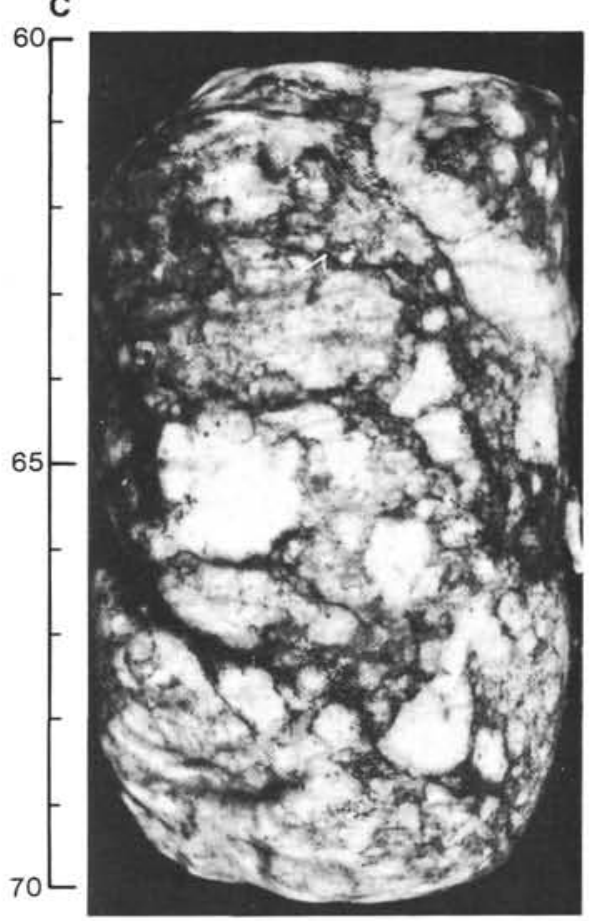

Figure 7. A-C. Photographs of examples of gas hydrates recovered at Sites 568 and 570 of Leg 84 (Sections 568-43-1 [A] and 570-26-5 [B]; and Core 570-27 [C]).

Huene, this volume). Methane in the gas hydrates found on Leg 84 was mainly derived in situ by biogenic processes, whereas the accompanying small amounts of ethane likely resulted from low-temperature diagenetic processes.

In order to form hydrate, permeability and porosity are required. Along the Middle America Trench, the hemipelagic slope deposits have extremely low permeability; therefore most hydrate may be found in sediment that has become consolidated enough to fracture. As free gas migrates upward through the fractures it becomes hydrated. The large transverse fault near Site 570 may have formed a zone through which gas could migrate and collect as hydrate to form the massive body cored there.

Finding gas hydrates on Leg 84 expands observations made earlier on Leg 66 and particularly Leg 67 . The results of all these legs show that gas hydrates are common in landward slope sediments of the Middle America Trench from Mexico to Costa Rica.

\section{CONCLUSIONS}

Leg 84 results complement those of Leg 67 and together these results provide many more observations than are available along most modern active margins (Fig. 9). The two legs and associated geophysical surveys provide a multidisciplinary data set that focuses interpretations concerning accretion and sedimentation. During Leg 67 the hole that penetrated through the Trench axis sediment pond and into the subducting oceanic crust was drilled. Similarly, the sediment of the landward slope has been penetrated to basement at more sites than along any other DSDP active margin transect. However, despite its status as one of the best-studied modern margins, there are still several critical targets that have not been drilled or surveyed with appropriate geophysical instruments.

Prior to Leg 84, the results of Leg 67 indicated a Miocene age for the ocean crust. Seabeam mapping shows the horst and graben structure of the oceanic Cocos 


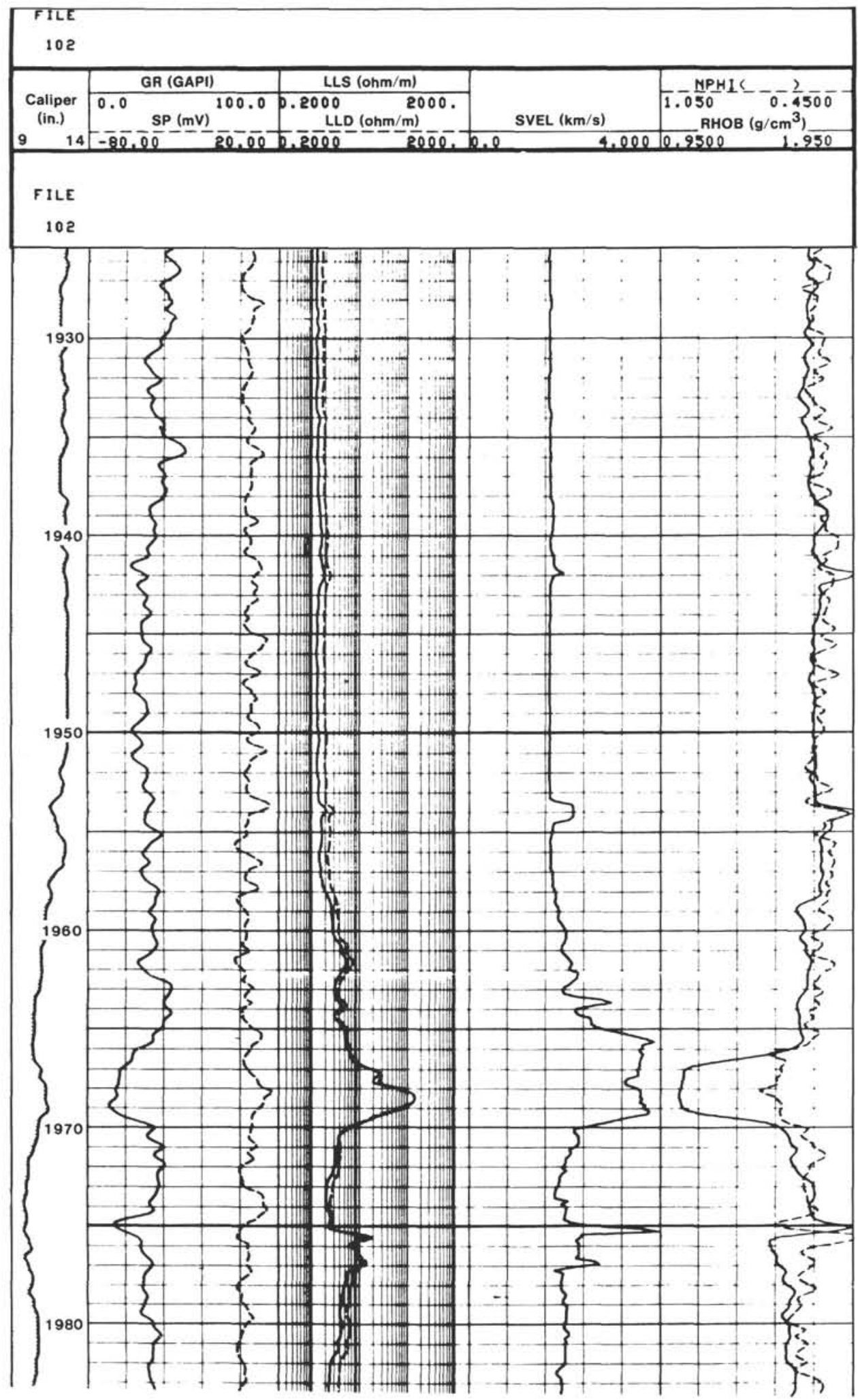

Figure 8. Schlumberger well log showing the log responses for a portion of the hole at Site 570 . From left to right the logs are caliper, gamma ray, self potential, resistivity (shallow and deep), sonic velocity, neutron porosity, and bulk density. Depth (water plus sediment) scale (m) is on the left. Each division represents $1 \mathrm{~m}$. The physical properties of gas hydrate beds $(\mathrm{V} \simeq 3.6 \mathrm{~km} / \mathrm{s}, \mathrm{d} \simeq 1)$ are very pronounced; they are easy to recognize, as, for example, between 1965 and $1970 \mathrm{~m}$. By comparison, the sandstones give a high velocity and a high density close to 2 (examples at 1954 and $1975.5 \mathrm{~m}$ ). 


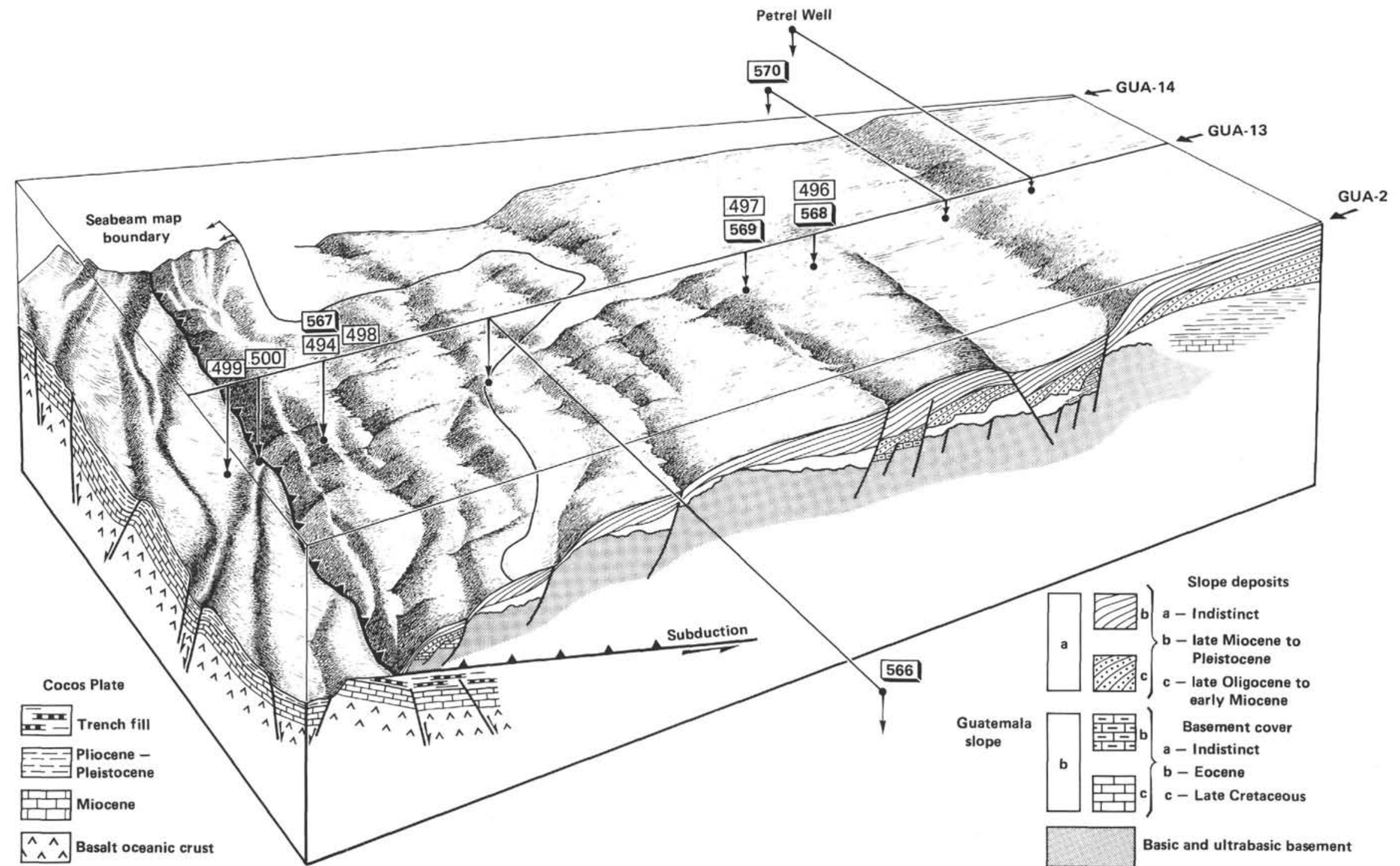

Figure 9. Block diagram showing the convergent zone between the Cocos Plate and the Caribbean (Central America) Plate in the Middle America Trench off Guatemala (after Aubouin, von Huene et al., 1982). This diagram includes the locations of the seismic, Seabeam, and deep-tow surveys, and Legs 67 and 84 sites. 
Plate that develops oblique to the trend of the Trench and produces a succession of diamond-shaped basins (graben) separated by the ridges (horst). Leg 67 drilling also revealed the abundant hemipelagic sediment that crossed the Trench axis and composes the upper half of the section on the subducting Cocos Plate. But on the continental slope, drilling was abandoned at all but one hole for safety reasons when gas hydrate was encountered. At only one site $1.5 \mathrm{~km}$ landward of the Trench axis was Upper Cretaceous (Upper Campanian-Maestrichtian) sedimentary rock recovered directly on igneous rock. This unexpected discovery raised the possibility that a nonaccretionary regime has existed since the Late Cretaceous along the Trench off Guatemala. But this conclusion remained in question because at the time further drilling was not allowed.

Leg 84 was therefore dedicated to the exploration of the continental slope with two major objectives: (1) to drill through the Neogene slope deposits and sample the proposed accretionary complex or, conversely, to reach the basement; and (2) to study the occurrence of gas hydrate.

A secondary objective proposed during Leg 67 was to drill off the Nicoya Peninsula of Costa Rica a reference site for the usual sequence drilled at the base of the slope off Guatemala (Site 494). This objective could not be realized because of the presence of gas hydrate in a vitric ash bed above the target depth; the hole was abandoned to gain time for the major objectives off Guatemala. The loss of $5000 \mathrm{~m}$ of drill pipe during logging of the second site off Guatemala (Site 567) limited the depth of further drilling. It was no longer possible to drill sites on the lower slope as was planned, and during the remainder of the leg drilling was restricted to sites on the middle and upper slope.

The two main objectives off Guatemala were met despite the loss of drill pipe. Basement of the continental slope was recovered at four sites; gas hydrate was also recovered at four sites, and a complete set of logs through a 4-m-thick massive methane hydrate at Site 570 provided a quantitative estimate of the in situ volume of hydrate. The success in reaching targeted drilling objectives allows four major conclusions as follows:

1. The pre-Late Cretaceous ophiolitic basement of the continental slope was emplaced prior to the present arc-trench system. At the sites where basement was penetrated, the age of the sediment covering the ophiolitic rock was early Miocene (567), early Eocene (569 and 570), and late Miocene in San José Canyon where the sedimentary section was once completely stripped from the basement (566). The sites are distributed transverse to the margin and are laterally separated by as much as $100 \mathrm{~km}$. Peridotite (harzburgite), gabbro, dolerite, basalt, and abundant serpentinite in various stages of alteration were recovered. These rocks have a metamorphic grade from low-temperature to greenschist facies and were tectonically juxtaposed without particular order. The Guatemalan margin is therefore underlain by tectonically disrupted ophiolitic rocks that are at least pre-Eocene and probably pre-Campanian, in agreement with the radiometric ages and the Cretaceous limestone recovered from two sites. The ophiolitic rock was tectonized and the resulting tectonic complex was emplaced prior to development of the present arc-trench system. Clasts of ophiolitic rock are found in the Oligocene to lower Miocene slope sediment particularly at the base of the slope where debris flows contain large blocks (ca. $50 \mathrm{~m}$ ) of serpentinized peridotite.

The ophiolitic and sedimentary rocks off Guatemala are petrologically, structurally, and chronologically similar to both the Santa Elena peridotites, the Nicoya complex of Costa Rica, and the Guatemalan Santa Clara ophiolite. Hence the crust beneath the continental slope off Guatemala is probably an extension of the crust beneath parts of Middle America, but this statement simplifies a complicated area. Middle America is broken into a number of microplates or blocks, and several occur between Costa Rica and Guatemala. Felsic plutonic rocks outcrop in Honduras and further complicate interpretations of Central American basement.

2. Neogene subduction-accretion, whereby sediment from the oceanic plate is scraped off and attached to the upper plate, is not seen within the area studied. In the northern Middle America Trench off Mexico, the Leg 66 staff made indirect arguments for accretion of Trench sediment based on the coarse-grained sediment recovered from the Trench axis and the lack of similar sediment in slope deposits. Implied in the interpretation is the presence of coarse sand only in the Trench and its exclusion from the slope (cf., Watkins, Moore, et al., 1982). Such an argument cannot be applied to the area studied off Guatemala. The hollows and topographic flat areas off Guatemala have lower Miocene ponded sediment and prograding sediment bodies that contain more sand than was found in the ponded sediment of the Trench axis. Sand was also recovered in channels, demonstrating again that the channels are transport paths directly to the Trench axis. Many local unconformities and hiatuses were detected in the slope deposits of sedimentary rather than tectonic origin. It seems that as one depocenter is accumulating sediment, another may lose its feeder channel and temporarily be in an interchannel or erosional area. The presence of coarse sand and rapid sediment accumulation is not an exclusive criterion by which trench and slope sediment can be differentiated off Guatemala. As a matter of fact, if the cores from the Guatemalan margin were studied without knowledge of their position on the slope or in the Trench axis, textural criteria alone would be of little use in showing their provenance.

As we have emphasized previously, the front of the Guatemalan margin consists of Mesozoic rock covered by slope sediment (Aubouin, von Huene, Arnott, et al., 1982). No Neogene accreted sediment has been sampled nor have any low velocities or densities indicating accreted sediment bodies been detected geophysically. The strength of the evidence for nonaccretion off Guatemala make this a tectonic type end-member, however, the mechanisms whereby accretion or nonaccretion dominate the tectonics of a convergent margin are not known.

3. Despite plate convergence, little compressional structure is detected in the rocks cored and in the seis- 
mic reflection records along the Guatemalan active margin transect. The seaward side of the Middle America Trench off Guatemala is formed by the downward flexure of the Cocos Plate into the subduction zone. Bending of the Plate produces stress that is accommodated by extensional tectonic failure along the grain inherited by the crust during its formation at the East Pacific Rise. Thus the horst and graben parallel the magnetic anomaly pattern of the Cocos Plate that is oblique to the Trench axis. On the other side of the Trench axis, a local complementary set of extensional structures signifies downslope failure so that along the transect, the Trench is essentially a graben despite the anticipated dominantly compressional forces from subduction.

The secondary extensional structure along this transect, in a system dominated primarily by compressional forces, requires very low friction along the subduction zone. We were able to test the hypothesis that elevated pore-fluid pressures exist in the subduction zone with a direct measurement just tens of meters above the subduction zone at Site 567. A minimum measured pressure of $350 \mathrm{psi}$ (pounds per square inch) above hydrostatic pressure is an explanation for the high degree of decoupling that is required to subduct soft sediment beneath a mass of ophiolitic rock. Indeed, high pore pressure appears to be common across the Guatemalan convergent margin, because it was similarly observed by direct measurement at the bottom of three other drill holes in the middle and upper slope, and kilometers above the subduction zone.

One feature emphasized in early studies of seismic data was a landward-dipping reflection beneath the upper slope (Ladd et al., 1982). This reflection is truncated by younger reflections produced during the present arctrench system; thus it was emplaced during a prior tectonic regime. The landward-dipping feature could be either from a sedimentary layer, perhaps Cretaceous limestone interleaved with ophiolite, or a thrust related to the pre-Eocene tectonism of the Cretaceous basement of Central America.

The Middle America Trench off Guatemala has been proposed as the model of a convergent-extensional active margin (Aubouin, Bourgois, et al., 1982, 1984). Such a margin has no accretion and displays extensional faulting, much like a passive margin with tilted blocks, but it is above a subduction zone. Such a margin is in contrast to a convergent compressional margin, where accretion accompanies subduction. The Barbados Ridge is the drilled example (see Moore, Biju-Duval, 1984) of the convergent compressional margin, where the upper part of the convergent sedimentary section is detached and accreted by imbricate thrusting and the lower part is subducted with the igneous oceanic crust. Although both types of margins accompany subduction, the convergent extensional margin seems to have a thin layer of sediment, whereas the convergent compressional margin involves a relatively thick layer of sediment. This idea could be tested along a single margin, such as the Antilles margin, where the southern part is sediment-flooded and the northern part is sediment-starved. In fact, the Peru-Chile, the Java, and the Aleutian trenches provide the same type of contrasting sediment-flooded and sediment-starved settings for such investigations.

4. Methane gas hydrate is ubiquitous across the whole Guatemalan margin even where no base of gas-hydrate reflection was seen. Gas hydrate was observed interspersed in fine-grained sediment, occupying fractures in mudstone, and as a massive unit along a fault. From logs it was determined that the high acoustic velocity $(4 \mathrm{~km} / \mathrm{s})$ and low density $\left(1.0 \mathrm{~g} / \mathrm{cm}^{3}\right)$ interact to give a low impedance; thus the hydrate cannot be detected acoustically in massive mudstone because there is no acousticimpedance difference between mudstone and hydrate. However, hydrate contrasts well with free gas, and hence the base of gas-hydrate reflection. Estimates of the volume of hydrate from the downhole logging indicated less than $10 \%$ hydrate at Site 570 , the site where the greatest number of visual observations of hydrate in the core were made. Thus it follows that at Site 568, where only few observations of the hydrate were made in the cores, and where the logs gave no indication of gas hydrate, the volume of dispersed hydrate was also less than $10 \%$. Seismic reflection records across Site 568 show a well-developed base of gas-hydrate reflection. Therefore, a base of gas-hydrate reflection may be evident where the amounts of dispersed hydrate are less than $10 \%$.

Inorganic geochemical studies on Leg 84 confirm the proposed relationship between low values of salinity and chlorinity and the occurrence of gas hydrate. In all cases where gas hydrates were observed, the values of salinity and chlorinity were lower than in sediments where gas hydrates were absent. Most gas hydrates were composed of gases from microbial and early diagenetic processes. However, at two sites (566 and 570) gases were found in the serpentinite. The gases in serpentinite are probably a product of the thermal breakdown of organic matter, because they contain high concentrations of ethane as well as hydrocarbons as large as hexane and heptane. This raises the question of the upward migration of gas from subducted sediment along the Wadati-Benioff zone. Serpentinite is not known to generate hydrocarbons. Sediment in a subduction zone is subjected to increasing temperature as it is carried to deeper levels and would be a source of thermogenic gas. Another possible source of thermogenic gas are the bodies of Mesozoic sediment that became folded into the ophiolitic assemblage during the pre-Eocene development of the present forearc basement. Such gases would tend to migrate upward along tectonic disruptions with any trapped fluids. Such sources of hydrocarbon could be investigated isotopically at future active margin drilling sites.

\section{THE TECTONIC HISTORY OF THE MARGIN AND ITS SIGNIFICANCE IN THE EVOLUTION OF CENTRAL AMERICA}

The results of DSDP drilling, the offshore geophysical surveys, the data from the ESSO Petrel drill hole on the shelf, the geologic studies of the Nicoya and Santa Elena areas in Costa Rica, and the geologic studies of on-land Guatemala indicate a three-fold tectonic history. In the first period, ultramafic rock was thrust over 
autochthonous Jurassic-Cretaceous sediments and was in turn unconformably overlain by Campanian-Maestrichtian sediments. This tectonic event, evidenced on the Santa Elena Peninsula and in the Santa Clara ophiolite of Guatemala, could correspond with the initial tectonism of the Guatemalan ophiolitic rock and its associated Campanian-Maestrichtian sediment. In the second period, the edge of the present shelf began to rise in the late Paleocene through early Miocene. This uplift formed the present wide forearc basin in which a $10-\mathrm{km}$-thick section of sediment was ponded. During this period the unconformable Eocene sediment section was deposited on the continental slope. In the third period, from early Miocene to the present, the existing arc-trench system was established, and massive hemipelagic mudstone was deposited on the present continental slope. At the edge of the shelf, local areas emerged above sea level causing the unconformities now evident in the seismic stratigraphy. The present arc-trench system was certainly established in the late Oligocene, as evidenced by the age of the first substantial layers of volcanic ash in the slope sediment section. Although Eocene volcanic ash was recovered offshore and is commonly found on land in Central America, the tectonic setting of that volcanism cannot be reconstructed off Guatemala. Tectonism of the arc-trench type appears to have continued throughout the Neogene punctuated by local uplift of the upper slope in the Pliocene and Pleistocene. San José Canyon has been the path for sediment transiting the slope to the Trench since the late Miocene. The lower reaches of the Canyon are now disrupted by normal faults that produced benches. The shape and structure of the benches indicate an area of collapse at the front of the margin.

Four tectonic processes in an arc-trench system are exemplified in the Guatemalan margin. First, as the Pacific Ocean crust is flexed downward into the Trench, it fails along the grain inherited during its emplacement on the East Pacific Rise rather than parallel to the axis of the flexure. The resulting divergence in the trend between the horst and graben of the oceanic plate and the Trench axis is probably repeated along many active margins. Such oblique failure is to be expected anywhere magnetic anomalies are less than $30^{\circ}$ oblique to the axis of a trench (von Huene and Aubouin, 1982), but a swathmapping system is required for its detection. Second, an essentially total net subduction of sediment since the late Oligocene requires a mechanism whereby friction between the upper ophiolitic plate and the lower sedimentary sequence is very low. Perhaps the upper plate is essentially floating due to pore pressures at near lithostatic levels within the subduction zone. Third, the uplift at the edge of the shelf and on the upper slope appears local in space and episodic in time. Such uplift can be accomplished by underplating, whereby sediment is added above the subduction zone as it passes beneath the upper slope from the subducting sediment in the subduction zone. That the crust may be thickened locally in the area of uplift by compressional deformation is difficult to suggest here because the uplifted area is devoid of major compressional structures. And fourth, the tectonic regime at the edge of the shelf is poorly under- stood, however, the seismic and magnetic results indicate greater depths to basement beneath the shelf than beneath the upper slope. The exact configuration of the contact is obscured in seismic records, but the gross geometry can be produced by obduction, normal faulting, or transcurrent faulting. Obduction requires landward thrusting of the slope ophiolitic complex over the forearc sediment sequence. In the absence of compressional structure in strata of the forearc basin, the latter two processes are most likely. Normal faulting associated with the shelf-edge uplift could be tested with a high-resolution multichannel seismic survey.

The results of Legs 67 and 84 and related geophysical studies have raised the level of questioning from the classical study of accretionary processes by Seely et al. (1974) to the following: How was the ophiolitic basement of Central America assembled into its present form and what does the landward-dipping reflection emphasized by Ladd et al. (1982) signify in terms of that pre-Eocene or perhaps Cretaceous assembly? What was the role of offshore strike-slip faulting prior to and after the late Oligocene? (Strike-slip faulting is common to this part of Central America on land.) Was some form of collision involved in the formation of the Central America basement? Such questions can perhaps be answered by coordinated on-land and offshore studies in the future.

\section{REFERENCES}

Aubouin, J., Azéma, J., Biju-Duval, B., Bourgois, J., Mascle, J., and Tardy, M., 1984. Subduction et orogénèse. Le prisme d'accrétion de la Barbade et l'absence d'accrétion le long de la fosse d'Amérique Centrale: deux processes prouvés et non exclusifs d'un phénomène crustal général, la subduction. C. R. Acad. Sci. Paris, 298(8): 351-358.

Aubouin, J., Bourgois, J., and Azéma, J., 1984. A new type of active margin: the convergent-extensional margin, as exemplified by the Middle America Trench off Guatemala. Earth Planet. Sci. Lett., 67:211-218.

Aubouin, J., Bourgois, J., von Huene, R., and Azéma, J., 1982. La marge pacifique du Guatemala: un modèle de marge extensive en domaine convergent. C. R. Acad. Sci. Paris, 295:607-614.

Aubouin, J., Stephan, J. F., Renard, V., Roump, J., and Lonsdale, P., 1981. Subduction of the Cocos plate in the Mid-America Trench. Nature, 94:146-150.

Aubouin, J., Stephan, J. F., Roump, J., and Renard, V., 1982. The Middle America Trench as an example of a subduction zone. Tectonophysics, 86:113-132.

Aubouin, J., von Huene, R., et al., 1982. Init. Repts. DSDP, 67: Washington (U.S. Govt. Printing Office).

Aubouin, J., von Huene, R., Arnott, R., Bourgois, J., Filewicz, M., et al., 1982. Subduction without accretion: Middle America Trench off Guatemala. Nature, 297:458-460.

Aubouin, J., von Huene, R., Azéma, J., Coulbourn, W. T., Cowan, D. S., et al., 1979. Premiers résultats des forages profonds dans le Pacifique au niveau de la fosse du Guatemala (fosse d'Amérique Centrale) (Leg 67 du Deep Sea Drilling Project: Mai-Juin, 1979). C. R. Acad. Sci. Paris, 289:1215-1220.

Aubouin, J., von Huene, R., and l'équipe Scientifique du Leg 84 du Glomar Challenger, 1982. Subduction sans accrétion: la marge pacifique du Guatemala: premiers résultats du Leg 84 du Deep Sea Drilling Project (Janvier-Février, 1982). C. R. Acad. Sci. Paris, 294:803-812.

Coulbourn, W. T., Hesse, R., Azéma, J., and Shiki, T., 1982. A summary of the sedimentology of Deep Sea Drilling Project Leg 67 sites: the Middle America Trench and slope off Guatemala-an active margin transect. In Aubouin, J., von Huene, R., et al., Init. Repts. DSDP, 67: Washington (U.S. Govt. Printing Office), 759-774. 
Cowan, D. S., 1982. Origin of "vein structure" in slope sediments on the inner slope of the Middle America Trench off Guatemala. In Aubouin, J., von Huene, R., et al., Init. Repts. DSDP, 67: Washington (U.S. Govt. Printing Office), 645-650.

Ibrahim, A. K., Latham, G. V., and Ladd, J., 1979. Seismic refraction and reflection measurements in the Middle America Trench offshore Guatemala. J. Geophys. Res., 84:5643-5649.

Ladd, J. W., Ibrahim, A. K., McMillen, K. J., Latham, G. V., and von Huene, R., 1982. Interpretation of seismic reflection data of the Middle America Trench offshore Guatemala. In Aubouin, J., von Huene, R., et al., Init. Repts. DSDP, 67: Washington (U.S. Govt. Printing Office), 675-690.

Ladd, J. W., Ibrahim, A. K., McMillen, K. J., Latham, G. V., von Huene, R. E., Watkins, J. E., Moore, J. C., and Worzel, J. L., 1978. Tectonics of the Middle America Trench off Guatemala. Int. Symp. Guatemala February 4 Earthquake and Reconstruction Process, Guatemala City, May, 1978.

Leterrier, J., Maury, R., Thonon, P., Girard, D., and Marchal, M., 1982. Clinopyroxene composition as a method of identification of the magmatic affinities of paleovolcanic series. Earth Planet. Sci. Lett., 59:139-154.

Minster, J. B., and Jordan, T. H., 1978. Present-day plate motions. J. Geophys. Res., 83:5331-5334.

Moore, G. F., Lonsdale, P., and von Huene, R., 1982. Near-bottom observations of the Middle America Trench off Guatemala. In Aubouin, J., von Huene, R., et al., Init. Repts. DSDP, 67: Washington (U.S. Govt. Printing Office), 707-718.

Moore, J. C., and Biju-Duval, B., 1984. Tectonic synthesis, Deep Sea Drilling Project Leg 78A: structural evolution of offscraped and underthrust sediment, northern Barbados Ridge complex. In BijuDuval, B., Moore, J. C., et al., Init. Repts. DSDP, 78A: Washington (U.S. Govt. Printing Office), 601-621.
Moore, J. C., Watkins, J., Bachman, S. B., Beghtel, F. W., Butt, A., et al., 1979. The Middle America trench off Mexico. Geotimes, 24: 20-22.

Murauchi, S., and Ludwig, W. J., 1980. Crustal structure of the Japan Trench: effect of subduction of ocean crust. In Scientific Party, Init. Repts. DSDP, 56, 57, Pt. 1: Washington (U.S. Govt. Printing Office), 463-470.

Renard, V., Aubouin, J., Lonsdale, P., and Stephan, J. F., 1980. Premiers résultats d'une étude de la fosse d'Amérique centrale au sondeur multifasceaux (Seabeam). C. R. Acad. Sci. Paris, 291:137-142.

Seely, D. R., 1979. Geophysical investigations of continental slopes and rises. In Watkins, J. S., and Montadert, L. (Eds.), Geological and Geophysical Investigation of Continental Margins, Am. Assoc. Pet. Geol. Mem., 51:245-260.

Seely, D. R., Vail, P. R., and Walton, G. G., 1974. Trench slope model. In Burk, C. A., and Drake, C. L. (Eds.), Geology of Continental Margins: New York (Springer-Verlag), pp. 261-283.

Shervais, J. W., 1982. Ti-V plots and the petrogenesis of modern and ophiolitic lavas. Earth Planet. Sci. Lett., 59:101-118.

Shipley, T. H., Houston, M. H., Buffler, R. T., Shaub, F. J., McMillen, K. J., Ladd, J. W., and Worzel, J. L., 1979. Seismic evidence for widespread possible gas hydrates horizons on continental slopes and rises. Am. Assoc. Pet. Geol. Bull., 63:2204-2213.

von Huene, R., and Aubouin, J., 1982. Summary-Leg 67, Middle America Trench transect off Guatemala. In Aubouin, J., von Huene, R., et al., Init. Repts. DSDP, 67: Washington (U.S. Govt. Printing Office), 775-796.

von Huene, R., Azéma, J., Blackinton, G., Carter, J. A., Coulbourn, W. T., et al., 1980. DSDP Mid-America Trench transect off Guatemala. Geol. Soc. Am. Bull., 91:421-432.

Watkins, J. S., Moore, J. C., et al., 1982. Init. Repts. DSDP, 66: Washington (U.S. Govt. Printing Office). 